\title{
Induction chemotherapy with cisplatin plus weekly paclitaxel followed by chemoradiotherapy for locally advanced squamous cell carcinoma of the head and neck
}

Quimioterapia de indução com cisplatina e paclitaxel semanal seguida de quimiorradioterapia para carcinoma de células escamosas de cabeça e pescoço localmente avançado

Sargeele Silva ${ }^{1}$, Rafael Grochot ${ }^{1}$, Debora Cristina Weschenfelder ${ }^{1}$, Cláudio Pescador ${ }^{1}$, Catherine Gotardo', Diego Gnatta', André Reiriz'1, Janaina Brollo'

\begin{abstract}
The paclitaxel-cisplatin is a non-infusional alternative for induction chemotherapy (IC) for LASCCHN based on phase-II trials. Here, we describe our institutional experience with this combination in Southern Brazil. Methods: Thirty-three consecutive patients with unresectable LASCCHN were selected between April/2012 and June/2014. They received weekly paclitaxel $80 \mathrm{mg} / \mathrm{m}^{2}$ on days $1,8,15$ and cisplatin $75 \mathrm{mg} / \mathrm{m}^{2}$ on day 1 for three cycles followed by chemoradiotherapy (CRT) with cisplatin at standard dose. Overall response, toxicity, progression free survival (PFS) and overall survival (OS) were evaluated. Results: The median follow-up was 25.5 months. Median age was 58.6 years and $96 \%$ had PS 1. Most patients presented with bulky disease at stages IVA and IVB (60.6\% and $21.2 \%$, respectively). Concerning primary site of tumor, 33.3\% were oropharingeal tumors, $27.3 \%$ larynx tumors and 33.3\% oral cavity tumors. The majority of patients had both smoking and alcohol abuse records. Twenty-eight patients $(84.8 \%)$ at the time of diagnosis had a $\mathrm{BMI}<25$. Twenty-seven patients $(81.8 \%)$ completed the planned treatment and three patients (9\%) underwent exclusive radiotherapy after IC. All patients were evaluated for response; $75.7 \%$ presented complete response and $21.2 \%$ presented partial response. Severe toxicity (grades 3-5) for asthenia, neutropenia, anemia and thrombocytopenia were observed in $6.1 \%, 9.1 \%, 6.1 \%$ and $3 \%$ of patients, respectively. One treatment-related death was associated with febrile neutropenia. The 2- and 3-year PFS rates were $63.3 \%$ and $68.4 \%$, respectively; 2 - and 3-year OS rates were $62.3 .5 \%$ and $50.6 \%$. Conclusions: Our results corroborate previous observations that IC (paclitaxel-cisplatin) is a well-tolerated and highly active regimen for the treatment of patients with LASSHNC, being associated with acceptable toxicity, good locoregional control and survival rates. This may be a good treatment option for patients in developing countries.
\end{abstract}

Keywords: Head and Neck Cancer; Induction Chemotherapy; Chemoradiation Therapy; Squamous Cell Carcinoma.

1. Hospital Geral de Caxias do Sul, Serviço de Oncologia - Caxias do Sul - RS - Brazil

Financial support: none to declare.

Conflicts of interest: The authors declare no conflict of interest relevant to this manuscript.

Correspondence author: Rafael Grochot. Departament of Medical Oncology, Caxias do Sul General Hospital.

Rua Professor Antônio Vignolli, 255, Bairro Petrópolis, Caxias do Sul, Brazil. Zip code: 95070-561.

E-mail: rmgrocho@ucs.br

Received on: August 13, 2018 | Accepted on: May 28, 2019

DOI: $10.5935 / 1806-6054.20190012$ 


\section{RESUMO}

O esquema paclitaxel-cisplatina é uma alternativa não-infusional como quimioterapia de indução (QI) para carcinomas escamosos de cabeça e pescoço localmente avançados, baseado em estudos de fase II. Descrevemos, aqui, nossa experiência institucional com esta modalidade de tratamento. Métodos: Trinta e três pacientes consecutivos diagnosticados com carcinoma escamoso de cabeça e pescoço localmente avançado, não-ressecável, foram selecionados entre abril/2012 e junho/2014. Receberam paclitaxel $80 \mathrm{mg} / \mathrm{m}^{2}$ nos dias 1, 8 e 15 + cisplatina $75 \mathrm{mg} / \mathrm{m}^{2}$ no D1 por três ciclos, seguidos por quimiorradioterapia com cisplatina em dose padrão. Foram avaliadas resposta global, toxicidade, sobrevida livre de progressão (SLP) e sobrevida global (SG). Resultados: A mediana de seguimento foi de 25,5 meses. A mediana de idade foi de 58,6 anos e $96 \%$ dos pacientes apresentaram PS 1. A maioria dos pacientes apresentou doença volumosa em estágios IVA e IVB (60,6\% e 21,2\%, respectivamente). Quanto ao sítio primário, 33,3\% eram tumores orofaríngeos, 27,3\% tumores de laringe e 33,3\% tumores de cavidade oral. Vinte e oito pacientes (84,8\%) apresentaram IMC $<25$ ao diagnóstico. Vinte e sete pacientes $(81,8 \%)$ completaram o tratamento planejado e três pacientes (9\%) foram submetidos à radioterapia exclusiva após QI. Todos os pacientes foram avaliados quanto à resposta; 75,7\% apresentaram resposta completa e 21,2\% apresentaram resposta parcial. Foi observada toxicidade grave (G3-5) para astenia, neutropenia, anemia e trombocitopenia em $6,1 \%, 9,1 \%, 6,1 \%$ e $3 \%$ dos pacientes, respectivamente. Um óbito relacionado ao tratamento foi atribuído à neutropenia febril. As taxas de SLP para 2 e 3 anos foram de 63,3\% e 68,4\%, respectivamente; as taxas de SG para 2 e 3 anos foram de 62,3,5\% e 50,6\%. Conclusões: Nossos resultados corroboram observações prévias de que QI (paclitaxel-cisplatina) é um regime bem tolerado e altamente ativo para o tratamento de pacientes com carcinomas escamosos de cabeça e pescoço localmente avançados, estando associado a toxicidade tolerável, controle locorregional e taxas de sobrevida satisfatórios. Esta pode ser uma opção de tratamento adequada a ser considerada para pacientes em países em desenvolvimento.

Descritores: Câncer de Cabeça e Pescoço, Quimioterapia de Indução, Quimiorradioterapia, Carcinoma de Células Escamosas.

\section{INTRODUCTION}

Head and neck tumors are the sixth most common diagnosed neoplasms worldwide, accounting for 650.000 new cancer cases and 350.000 cancer deaths every year. ${ }^{1}$ Most recent data from Instituto Nacional do Câncer (INCA) forecasts 14.700 and 7.670 new cases of oral cavity and larynx cancer, respectively, among Brazilians for the year of 2018. ${ }^{2}$ Unfortunately, most patients are diagnosed in clinical stages III or IV; ${ }^{3}$ according to the Fundação Oncocentro de São Paulo, they represent $75 \%$ of presenting cases. ${ }^{2,4}$ For those patients with LASCCHN (locally advanced squamous cell carcinoma of the head and neck), the prognosis is poor, $40-60 \%$ of patients relapse and $30-50 \%$ of patients survive for three years after treatment., 6 The standard treatment for locally advanced disease is based on a combination of chemotherapy and radiotherapy, requiring multidisciplinary approach. ${ }^{7-10}$
An attractive option that has been widely studied in this population is the use of induction chemotherapy (IC). When administered before chemoradiotherapy (CRT), it has the advantage of allowing responsive patients to begin definitive treatment with smaller tumor burdens, minor symptoms and better performance status. ${ }^{11,12}$ Phase III studies have shown that three drug-containing IC (i.e. Docetaxel, cisplatin and 5-fluorouracil [TPF], paclitaxel, cisplatin and 5-fluorouracil $[P C F]$ ) are associated with better results. ${ }^{11-14}$ Nevertheless, these regimens require careful monitoring of patients due to significant toxicity. Moreover, these protocols can be considerably expensive, since they require the use of the continuous infusion pumps, and prophylactic antibiotic therapy. ${ }^{11,14}$

Based on phase II trials, ${ }^{12,15}$ the aim of this paper was to evaluate the feasibility and outcome of a two-drug non-infusional IC combining cisplatin $\left(75 \mathrm{mg} / \mathrm{m}^{2}\right.$ ) and weekly paclitaxel $\left(80 \mathrm{mg} / \mathrm{m}^{2}\right)$ followed by CRT in LASCCHN. 


\section{METHODS}

\section{Study design and eligibility criteria}

We retrospectively analyzed medical records of all consecutive patients with LASCCHN (stages III and IV) of the oral cavity, larynx, oropharynx and hypopharynx treated on Caxias do Sul General Hospital with IC (cisplatin and weekly paclitaxel) followed by CRT from April, 2012 to June, 2014. We excluded patients with previous history of neoplasia and/or distant metastases at diagnosis. All patients in this study had histopathological confirmation of squamous cell carcinoma; all paranasal sinus and nasal cavity cancers were therefore excluded. Patient information such as age, gender, performance status (PS), clinical stage, primary tumor location, treatment dose, toxicities and outcomes were collected by the researchers. Data were analyzed using SPSS 2.0 program. Institutional ethical approval was obtained.

\section{Treatment characteristics}

\section{Induction chemotherapy}

Cisplatin $75 \mathrm{mg} / \mathrm{m}^{2}$ was administered on day 1 and subsequently every 21 days. Weekly paclitaxel 80 $\mathrm{mg} / \mathrm{m}^{2}$ was administered on days 1,8 and 15 every 21 days. IC was administered for three cycles, unless there was disease progression, unacceptable toxicity or consent withdrawal. Dose modifications were consistent with standard clinical practice. A cycle could be delayed for up to two weeks to allow severity of grade $\geq 3$ toxicity to regress to grade 1 .

\section{Concurrent treatment}

Chemoradiotherapy was initiated at a minimum interval of three weeks from IC completion. Cisplatin $\left(100 \mathrm{mg} / \mathrm{m}^{2}\right)$ was administered intravenously on days 1,22 and 43.

\section{Assessments}

\section{Safety}

Toxicity for IC was assessed every three weeks by leading researchers using the National Cancer Institute Common Toxicity Criteria version 4.0 (May, 2009). Patients were evaluated clinically and underwent biochemical tests.

\section{Efficacy}

Response criteria were evaluated according to RECIST guidelines. Complete response (CR) was defined as complete disappearance of all lesions. Partial response (PR) was defined as no new lesions in addition to a decrease of at least $30 \%$ in the sum of the largest tumor diameter in reference to baseline evaluation. Stable disease (SD) was defined as neither sufficient shrinkage to qualify for PR nor sufficient increase to qualify for progressive disease (PD). PD was defined as an increase of at least 20\% in the sum of the largest tumor diameter in reference to baseline evaluation or the appearance of one or more new lesions. Response rate was assessed by direct clinical examination, chest $\mathrm{X}$-ray and computed tomography of the head and neck after completion of IC, on weeks six and 12 after completion of CRT and during follow-up visits until PD or death from any cause.

All patients underwent CRT, regardless of response to IC, unless metastatic disease was diagnosed.

Progression free survival (PFS) was defined as time between date of initiation of therapy and PD or date of last follow-up. Overall survival (OS) was defined as time between date of diagnosis and date of death or date of last follow-up. PFS and OS were estimated by the Kaplan-Meier method.

\section{RESULTS}

\section{Patients}

Thirty-three patients diagnosed with squamous cell carcinoma of head and neck received IC with cisplatin and weekly paclitaxel from April, 2012 to June, 2014, in Caxias do Sul General Hospital. Average age was of 58.7 years and males accounted for the majority of the cohort $(97.1 \%)$. The most prevalent primary sites were oral cavity and oropharynx $32.4 \%$ for both), followed by nine patients with laryngeal tumors (27.3\%) and two hypopharynx tumors (6.1\%). PS 1 was reported for 32 patients (97.1\%). Only six patients (18.2\%) were diagnosed at clinical stage III, while $20(60.6 \%)$ and seven (21.2\%) patients presented clinical stages IVA and IVB, respectively. History of smoking was positive for 31 patients (93.9\%) and 27 patients reported alcohol abuse (81.8\%). Twenty-eight patients $(84.8 \%)$ presented with BMI (Body mass index) $<25 \mathrm{~kg} / \mathrm{m}^{2}$ (Table 1 ).

\section{Treatment Compliance}

Twenty-six patients (78.7\%) underwent three cycles of IC and four patients (12.1\%) underwent four cycles due to delay in initiating radiotherapy. Two patients $(6.1 \%)$ received only two cycles of IC because of severe toxicity and, therefore, treatment was suspended. One patient required CT dose reduction that was attributed to moderate toxicity.

Twenty-seven patients (81.8\%) completed concurrent chemoradiotherapy post-IC and three patients (9\%) were submitted to exclusive radiotherapy after IC due to renal toxicity and loss of PS.

\section{IC Adverse events}

All patients were evaluated for safety (Table 2). The most common adverse events were alopecia (90.9\%), nausea (63.6\%) and asthenia (66.7\%). Acute renal impairment was reported for five patients (15.2\%), 3\% being $\mathrm{G} 1$ and $12.1 \%$ being G2. Diarrhea and lack of appetite (G1-2) were both observed in 11 patients 
Table 1. Patient characteristics

\begin{tabular}{|c|c|c|}
\hline Variables & No of patients & $\%$ \\
\hline \multicolumn{3}{|l|}{ Sex } \\
\hline Male & 32 & 96,9 \\
\hline Female & 1 & 3,1 \\
\hline \multicolumn{3}{|l|}{ Age (years) } \\
\hline \multicolumn{3}{|l|}{ Median age 58.6} \\
\hline \multicolumn{3}{|l|}{ Range: 47-76 } \\
\hline Smoking & 31 & 93,9 \\
\hline Alcoholism & 27 & 81,8 \\
\hline \multicolumn{3}{|l|}{ Histological type } \\
\hline Squamous cell carcinoma & 33 & 100 \\
\hline \multicolumn{3}{|l|}{ Site of primary tumor } \\
\hline Oral Cavity & 11 & 33,3 \\
\hline Oropharynx & 11 & 33,3 \\
\hline Larynx & 9 & 27,3 \\
\hline Hypopharynx & 2 & 6,1 \\
\hline \multicolumn{3}{|l|}{ WHO performance status } \\
\hline 0 & 0 & 0 \\
\hline 1 & 32 & 97 \\
\hline 2 & 1 & 3 \\
\hline \multicolumn{3}{|l|}{ Stage of primary tumor $(\mathrm{T})$} \\
\hline $\mathrm{T} 1$ & 1 & 2,9 \\
\hline $\mathrm{T} 2$ & 4 & 12,1 \\
\hline T3 & 10 & 30,3 \\
\hline $\mathrm{T} 4 \mathrm{a}$ & 13 & 39,4 \\
\hline $\mathrm{T} 4 \mathrm{~b}$ & 5 & 15,2 \\
\hline \multicolumn{3}{|l|}{ Nodal Stage (N) } \\
\hline NO & 5 & 15,2 \\
\hline N1 & 8 & 24,2 \\
\hline $\mathrm{N} 2 \mathrm{a}$ & 11 & 33,3 \\
\hline $\mathrm{N} 2 \mathrm{~b}$ & 3 & 9,1 \\
\hline $\mathrm{N} 2 \mathrm{C}$ & 3 & 9,1 \\
\hline N3 & 3 & 9,1 \\
\hline \multicolumn{3}{|l|}{ AJCC/UICC staging system } \\
\hline III & 6 & 18,2 \\
\hline IVa & 20 & 60,6 \\
\hline \multicolumn{3}{|l|}{$\mathrm{IVb}$} \\
\hline BMI $\left(\mathrm{Kg} / \mathrm{m}^{2}\right)$ & 8 & 21,2 \\
\hline $\mathrm{BMI}<25$ & 28 & 84,8 \\
\hline $\mathrm{BMI} \geq 25$ & 5 & 15,2 \\
\hline
\end{tabular}

WHO performance status: World Health Organization Performance Status; BMI: body mass index. 
Table 2. Adverse Events

\begin{tabular}{lccccc}
\hline \multicolumn{5}{c}{ Induction chemotherapy } \\
\hline AE & Grade 1 & Grade 2 & Grade 3 & Grade 4 & Grade 5 \\
\hline Alopecia & $12(38.4 \%)$ & $18(54.5 \%)$ & 0 & 0 & 0 \\
Anemia & $2(6.1 \%)$ & $9(27.3 \%)$ & $2(6.1 \%)$ & 0 & 0 \\
Asthenia & $8(24.2 \%)$ & $11(33.3 \%)$ & $1(3 \%)$ & $1(3 \%)$ & 0 \\
Diarrhea & $7(21.2 \%)$ & $4(12.1 \%)$ & 0 & 0 & 0 \\
Febrile neutropenia & 0 & 0 & $1(3 \%)$ & $1(3 \%)$ & $1(3 \%)$ \\
Headache & $2(6.1 \%)$ & 0 & 0 & 0 & 0 \\
Inappetence & $7(21.2 \%)$ & $3(9.1 \%)$ & $1(3 \%)$ & 0 & 0 \\
Nausea & $14(42.4 \%)$ & $7(21.1 \%)$ & 0 & 0 & 0 \\
Nephropathy & $1(3 \%)$ & $4(12.1 \%)$ & 0 & 0 & 0 \\
Neuropathy & $2(6.1 \%)$ & 0 & 0 & 0 & 0 \\
Ototoxicity & 0 & $1(3 \%)$ & 0 & 0 & 0 \\
Thrombocytopenia & 0 & 0 & $1(3 \%)$ & 0 & 0 \\
\hline
\end{tabular}

AE: adverse events.

(33.3\%). One patient reported G2 ototoxicity and two patients $(6.1 \%)$ presented with headache and paresthesia (both G1).

As for hematologic events, anemia was observed in 13 patients (39.4\%) and thrombocytopenia was reported for 1 patient. Three patients (8.8\%) presented with febrile neutropenia; one death (G5) was attributed to this toxicity. Other serious adverse events (G35) were due to anemia (5.8\%), febrile neutropenia (5.8\%), lack of appetite (2.9\%) and asthenia (5.8\%).

\section{Efficacy}

The average follow-up time was of 25.5 months. After IC, PR was reported for seven patients (21.2\%) CR for 25 patients $(75.7 \%)$ and PD for one patient (3\%).

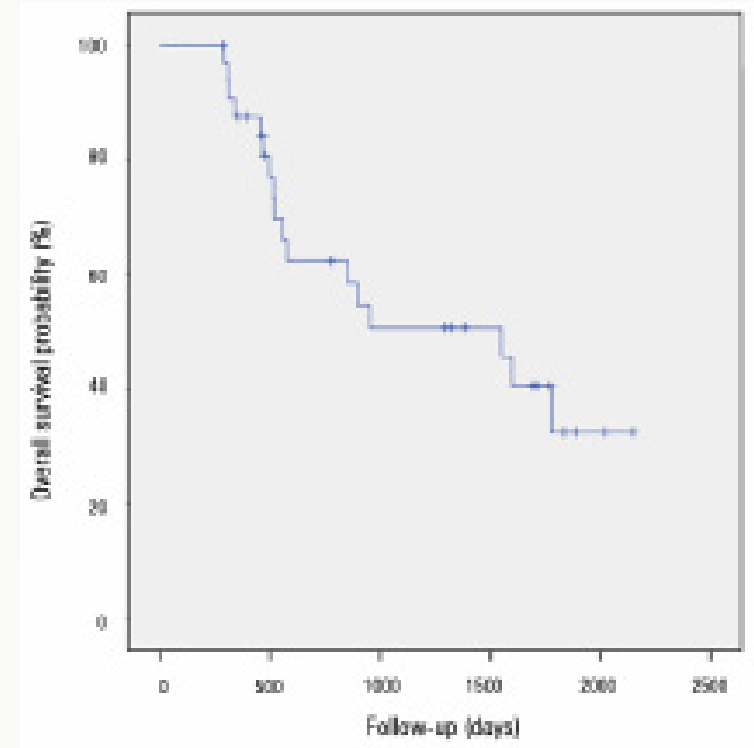

Then, $27(79,4 \%)$ patients were submitted to CRT and three patients (9\%) underwent exclusive radiotherapy (Table 3).

In the final analysis, 12 patients (36.3\%) presented with PD and 17 deaths (51.5\%) were related to neoplasm. The estimated OS in 2 years was of $62.3 \%$ and $50.6 \%$ in 3 years. The estimated PFS in 2 years was of $63.3 \%$ and $58.4 \%$ in 3 years (Figure 1 ).

Table 3. Treatment Response Rate

\begin{tabular}{lc}
\hline Partial response & $7(21,2 \%)$ \\
Complete response & $25(75,7 \%)$ \\
Stable disease & 0 \\
Progression & $1(3 \%)$ \\
\hline
\end{tabular}

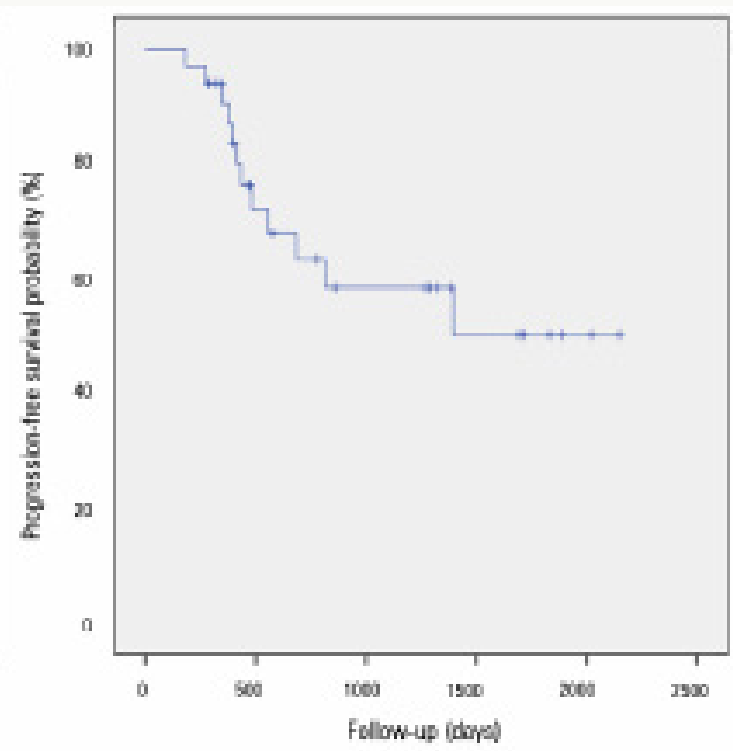

Figure 1. Kaplan-Meier Curves for Overall Survival and Progression-Free Survival. 


\section{DISCUSSION}

The management of head and neck cancer requires a multidisciplinary approach. ${ }^{16}$ Combined concomitant chemotherapy and radiotherapy is the current definitive standard approach for LASCCHN. Multiple phase III studies of both single-agent and combination chemotherapy given concurrently with radiation have demonstrated clear improvements in both locoregional control and survival. ${ }^{7}$ The large, well-conducted Meta-Analysis of Chemotherapy on Head and Neck Cancer (MACH-NC), reported first in $2000^{7}$ and updated in $2009^{14}$ confirmed these observations. In their updated analysis of 17.346 patients from 93 randomized trials that were conducted between 1965 and 2000, a 6.5\% 5-year absolute survival benefit (hazard ratio $[\mathrm{HR}]=0.81 ; 95 \% \mathrm{Cl}, 0.78-0.86 ; p=0.001$ ) was demonstrated favoring concurrent treatment. Nevertheless, this combination is associated with significant toxicities including mucositis, dysphagia, odynophagia, nausea, vomiting, anorexia, fatigue and dysgeusia, resulting in worsening of nutritional adequacy. This may be especially relevant for lower socio-economic status (SES) populations. Despite multiple phase III trials have failed to demonstrate a consistent survival benefit from IC approach, ${ }^{17}$ some data suggest that it might improve tumor local control. Patients from developing countries frequently present with bulky disease and symptomatic tumors that lead to difficulty eating prior to the initiation of treatment and consequently malnutrition at the time of diagnosis. The rationale behind the concept of induction-based therapies can be also related to potentially reducing metastatic disease, symptomatic relief, closer assessment of tumor responsiveness and organ preservation. ${ }^{18}$

To date, five phase III trials have compared IC using fluorouracil-cisplatin doublets versus three-drug regimens. ${ }^{13-19}$ In view of the consistently better overall response rate favoring three-drug IC, a general consensus emerged that the three-drug regimen is more active in LASCCHN. In our scenario, continuous infusion of 5-FU is not a feasible choice given the high costs of the proper gear, lack of structure for outpatient management and overcrowded beds for in-hospital treatment. It would inevitably implicate in delays of chemotherapy cycles, break of periodicity and consequent impairment of protocol effectiveness. Therefore, we adopted an outpatient IC regimen based on two phase II studies, revealing satisfactory response rates and tolerable toxicity. Both studies featured paclitaxel administered every 21 days. However, published data of other neoplasms suggest that weekly administration of paclitaxel as associated to a better tolerability profile and fewer side effects without losing efficacy. ${ }^{10,11}$

Barone et al. evaluated 35 patients with SCCHN (squamous cell carcinoma of the head and neck) treated with an IC regimen comprised of two courses of cisplatin $\left(100 \mathrm{mg} / \mathrm{m}^{2}\right)$ and paclitaxel $\left(175 \mathrm{mg} / \mathrm{m}^{2}\right)$ followed by standard radiotherapy concomitant to weekly cisplatin $\left(30 \mathrm{mg} / \mathrm{m}^{2}\right)$. After IC, an overall response was observed in $63 \%$ of patients $(9 \% \mathrm{CR}$, $54 \%$ PR) and after concomitant CRT, $46 \%$ of patients achieved CR and 12\% PR. Toxicity was mild during IC; 14\% developed G3-4 neutropenia without febrile neutropenia. Asthenia, nausea and emesis were the most frequent toxicity events (G1-2) and two patients developed nephrotoxicity. Median time to progression was of 10.7 months; 2- and 3-year survival rates were of $30 \%$ and $25 \%$ respectively. ${ }^{15-20}$ In another prospective multicenter phase-II trial, Dietz and colleagues treated 71 patients with cisplatin (100 $\left.\mathrm{mg} / \mathrm{m}^{2}\right)$ and paclitaxel $\left(200 \mathrm{mg} / \mathrm{m}^{2}\right)$ on days 1 and 22 . Patients with CR or PR proceeded to radiotherapy and non-responders underwent total laryngectomy followed by postoperative radiotherapy. Response rate to IC for larynx cancer was of $69.6 \%(7.1 \%$ CR, $62.5 \%$ PR) and for hypopharyngeal cancer was of 84.3\% (6.9\% CR, 77.4\% PR). Estimated OS after 36 months was of $60.3 \%(95 \% \mathrm{Cl}, 48.4-72.2 \%)$ and after 42 months was of $41.3 \%(95 \% \mathrm{Cl}, 29.3-53.3 \%) .^{12}$ Recently, Viana et al reproduced similar results in another phase II study with cisplatin-paclitaxel IC. ${ }^{21}$

In our study, all patients presented with high risk locally advanced disease; T4 tumors were documented in $54.6 \%$ of the cohort and $72.7 \%$ for N2-3 diseases. The objective response rate was CR $75.7 \%$ and PR $21.2 \%$ after IC. These results compared favorably to the results reported by other phase II trials in which the objective response was achieved in $79-86 \%$ of tumors. The high locoregional control rate at the end of treatment may be attributed to a satisfactory cytoreduction before starting radiation as a result of better drug delivery to the tumor. Importantly, 79.4\% of patients completed successfully the sequential CRT treatment. Besides, PFS and OS rates were also similar to previously reported results. The last European consensus for SCCHN reported that relative survival rate for head and neck cancer patients was of $72 \%$ at 1 year and $42 \%$ at 5 years in adults. ${ }^{22}$

The main risk factors for SCCHN are tobacco and alcohol consumption, accounting for approximately $75-90 \%$ of cases and a 30 times risk increase when combined..$^{20}$ In addition, HPV has been implicated as a causative agent in a subset of SCCHN, specifically those arising in the oropharynx. We observed that $93.9 \%$ of our patients had history of previous smoking and $81.8 \%$ of them reported alcohol abuse. A systematic review of worldwide literature conducted by Kreimer et al. reported that HPV-DNA was detected in 35.6\% of oropharyngeal cancers, with HPV type 16 accounting for the vast majority (87\%) of HPV-positive cases. ${ }^{23}$ So far, our local epidemiology consists of a heavily smoking and alcoholic population, which differs from worldwide data regarding HPV status. ${ }^{24,25}$

Patients with head and neck cancer frequently experience malnutrition. More than $50 \%$ of SCCHN patients exhibit significant weight loss at time of diagnosis and immediately before treatment. ${ }^{25,26}$ The weight loss can be mostly attributed to cancer-induced cachexia, anorexia, dysphagia and odynophagia. Recently, 8.306 head and neck cancer patients were examined and $\mathrm{BMI}<25$ impacted in worse survival rates, higher disease related mortality, higher recurrence and distant 
metastasis rates. ${ }^{26}$ In addition, McRanckan and co-authors suggest that CRT patients with BMI greater than 25 evolve with improved swallowing quality, longer time to disease recurrence, and improved survival when compared with similar patients with lower BMI. Therefore, BMI revealed to be a prognostic factor for survival, regardless of primary tumor site and stage in head and neck cancer, and should be considered as an important clinical factor when determining optimal treatment modality. ${ }^{27}$ This is another interesting point for our population, since $84.8 \%$ of patients presented with $\mathrm{BMl}<25$ at diagnosis.

Worse survival outcomes have been previously associated with lower SES on other neoplasms. ${ }^{27,28}$ This relationship seems to be multifactorial and might be involved with tumor presentation at diagnosis, access to healthcare and education, diet, environmental exposure and different levels of tobacco and alcohol consumption. ${ }^{29,30}$ Head and neck cancers display some of the largest SES disparities impacting in survival among all cancers. ${ }^{31}$ The differences in
5- and 10-year survival from laryngeal cancer between wealthy and impoverished populations have been reported to be $17 \%$ and $11 \%$, respectively. ${ }^{31}$ Considering our institution is a public health facility, we emphasize that the socio-economic profile of our patients cannot be disregarded.

The strengths of our study include the comprehensive nature of the registry database with patient demographics, clinical characteristics, pathological features, description of treatments received and complete ascertainment of patient status at regular follow-up intervals with evaluation of adverse events. Similarly to other developing countries, our study comprises a diverse set of patients that differ in terms of bulky tumor presentation, highly symptomatic, inferior BMI, considerable exposure history and socio-environmental conditions. Still, we acknowledge the several limitations to the present study, including its retrospective nature, small cohort of patients and the fact that IC is not yet considered standard-of-care for LASCCHN.

\section{CONCLUSION}

Our results corroborate previous observations that IC (paclitaxel-cisplatin) is a well-tolerated and highly active regimen for the treatment of patients with LASSHNC. IC with cisplatin plus weekly paclitaxel is feasible, tolerable and relatively safe; notwithstanding, considerable toxicity cannot be ignored. This treatment improved local control at the expense of acceptable adverse events, adequate locoregional control and survival rates in a population with high risk locally advanced tumor with bulky disease, inferior SES and low BMI. This regimen might be a good option for treatment of patients in developing countries.

\section{REFERENCES}

1. Jemal A, Bray F, Center MM, Ferlay J, Ward E, Forman D. Global cancer statistics. CA Cancer J Clin. 2011;61(2):69-90.

2. Brazil. Instituto Nacional de Câncer José Alencar Gomes da Silva (INCA). Estimativa 2018. Incidência de Câncer no Brasil. Rio de Janeiro: INCA; 2017. [cited 2018 Oct 30]. Available from: https:// www.inca.gov.br/publicacoes/livros/estimativa-2018-incidencia-de-cancer-no-brasil

3. Seiwert TY, Cohen EE. State-of-the-art management of locally advanced head and neck cancer. Br J Cancer. 2005;92(8):1341-8.

4. Conway DI, Hashibe M, Boffetta P, Wunsch-Filho V, Muscat J, La Vecchia C, et al.; INHANCE consortium. Enhancing epidemiologic research on head and neck cancer: INHANCE - The international head and neck cancer epidemiology consortium. Oral Oncol. 2009;45(9):743-6.

5. Posner MR, Haddad RI, Wirth L, Norris CM, Goguen LA, Mahadevan A, et al. Induction chemotherapy in locally advanced squamous cell cancer of the head and neck: evolution of the sequential treatment approach. Semin Oncol. 2004;31(6):778-85.
6. Lefebvre JL, Chevalier D, Luboinski B, Kirkpatrick A, Collette L, Sahmoud T. Larynx preservation in pyriform sinus cancer: preliminary results of a European Organization for Research and Treatment of Cancer phase III trial. EORTC Head and Neck Cancer Cooperative Group. J Natl Cancer Inst. 1996;88(13):890-9.

7. Pignon JP, Bourhis J, Domenge C, Designé L. Chemotherapy added to locoregional treatment for head and neck squamous-cell carcinoma: three meta-analyses of updated individual data. MACH-NC Collaborative Group. Meta-Analysis of Chemotherapy on Head and Neck Cancer. Lancet. 2000;355(9208):949-55.

8. Pignon JP, le Maître A, Bourhis J; MACH-NC Collaborative Group. Meta-Analyses of Chemotherapy in Head and Neck Cancer (MACH-NC): an update. Int J Radiat Oncol Biol Phys. 2007;69(2 Suppl):S112-4.

9. Bourhis J, Amand C, Pignon JP. Update of MACHNC (Meta-Analysis of Chemotherapy in Head \& Neck Cancer) database focused on concomitant chemoradiotherapy. J Clin Oncol. 2004;22(14 Suppl):5505. 
10. Michiels S, Le Maître A, Buyse M, Burzykowski T, Maillard E, Bogaerts J, et al.; MARCH and MACHNC Collaborative Groups. Surrogate endpoints for overall survival in locally advanced head and neck cancer: meta-analyses of individual patient data. Lancet Oncol. 2009;10(4):341-50.

11. Pointreau Y, Garaud P, Chapet S, Sire C, Tuchais C, Tortochaux J, et al. Randomized trial of induction chemotherapy with cisplatin and 5-fluorouracil with or without docetaxel for larynx preservation. J Natl Cancer Inst. 2009;101(7):498-506.

12. Dietz A, Rudat V, Dreyhaupt J, Pritsch M, Hoppe $F$, Hagen R, et al. Induction chemotherapy with paclitaxel and cisplatin followed by radiotherapy for larynx organ preservation in advanced laryngeal and hypopharyngeal cancer offers moderate late toxicity outcome (DeLOS-I-trial). Eur Arch Otorhinolaryngol. 2009;266(8):1291-300.

13. Hitt R, López-Pousa A, Martínez-Trufero J, Escrig V, Carles J, Rizo A, et al. Phase III study comparing cisplatin plus fluorouracil to paclitaxel, cisplatin, and fluorouracil induction chemotherapy followed by chemoradiotherapy in locally advanced head and neck cancer. J Clin Oncol. 2005;23(34):8636-45.

14. Pignon JP, le Maître A, Maillard E, Bourhis J; MACHNC Collaborative Group. Meta-analysis of chemotherapy in head and neck cancer (MACH-NC): an update on 93 randomised trials and 17,346 patients. Radiother Oncol. 2009;92(1):4-14.

15. Barone C, Grillo R, Dongiovanni D, Birocco N, Rampino M, Redda MG, et al. Induction chemotherapy followed by concurrent chemoradiotherapy in advanced head and neck squamous cell carcinoma. Anticancer Res. 2008;28(2B):1285-91.

16. Forastiere AA, Adelstein DJ, Manola J. Induction chemotherapy meta-analysis in head and neck cancer: right answer, wrong question. J Clin Oncol. 2013;31(23):2844-6.

17. Haddad RI, Posner M, Hitt R, Cohen EEW, Schulten J, Lefebvre JL, Vermorken JB. Induction chemotherapy in locally advanced squamous cell carcinoma of the head and neck: role, controversy, and future directions. Ann Oncol. 2018;29(5):1130-1140. DOI: 10.1093/annonc/ mdy 102

18. Pointreau Y, Atean I, Fayette J, Calais G, Lefebvre JL. Induction chemotherapy in head and neck cancer: a new paradigm. Anticancer Drugs. 2011;22(7):613-20.

19. Lorch JH, Goloubeva O, Haddad RI, Cullen K, Sarlis N, Tishler R, et al.; TAX 324 Study Group. Induction chemotherapy with cisplatin and fluorouracil alone or in combination with docetaxel in locally advanced squamous-cell cancer of the head and neck: long-term results of the TAX 324 randomised phase 3 trial. Lancet Oncol. 2011;12(2):153-9.
20. Ang KK, Harris J, Garden AS, Trotti A, Jones CU, Carrascosa $\mathrm{L}$, et al. Concomitant boost radiation plus concurrent cisplatin for advanced head and neck carcinomas: radiation therapy oncology group phase II trial 99-14. J Clin Oncol. 2005;23(13):3008-15.

21. de Souza Viana L, de Aguiar Silva FC, Andrade Dos Anjos Jacome A, Calheiros Campelo Maia D, Duarte de Mattos M, Arthur Jacinto A, et al. Efficacy and safety of a cisplatin and paclitaxel induction regimen followed by chemoradiotherapy for patients with locally advanced head and neck squamous cell carcinoma. Head Neck. 2016;38(Suppl 1):E970-80.

22. Grégoire V, Lefebvre JL, Licitra L, Felip E; EHNS-ESMO-ESTRO Guidelines Working Group. Squamous cell carcinoma of the head and neck: EHNS-ESMO-ESTRO Clinical Practice Guidelines for diagnosis, treatment and follow-up. Ann Oncol. 2010;21(Suppl 5):v184-6.

23. Kreimer AR, Clifford GM, Boyle P, Franceschi S. Human papillomavirus types in head and neck squamous cell carcinomas worldwide: a systematic review. Cancer Epidemiol Biomarkers Prev. 2005;14(2):467-75.

24. Gillison ML, Lowy DR. A causal role for human papillomavirus in head and neck cancer. Lancet. 2004;363(9420):1488-9.

25. O'Neill JP, Shaha AR. Nutrition management of patients with malignancies of the head and neck. Surg Clin North Am. 2011;91(3):631-9.

26. Hollander DD, Kampman E, van Herpen CM. Pretreatment body mass index and head and neck cancer outcome: A review of the literature. Crit Rev Oncol Hematol. 2015;96(2):328-38.

27. McRackan TR, Watkins JM, Herrin AE, Garrett-Mayer EM, Sharma AK, Day TA, et al. Effect of body mass index on chemoradiation outcomes in head and neck cancer. Laryngoscope. 2008;118(7):1180-5.

28. Johnson S, McDonald JT, Corsten M. Oral cancer screening and socioeconomic status. J Otolaryngol Head Neck Surg. 2012;41(2):102-7.

29. Booth CM, Li G, Zhang-Salomons J, Mackillop WJ. The impact of socioeconomic status on stage of cancer at diagnosis and survival: a population-based study in Ontario, Canada. Cancer. 2010;116(17):4160-7.

30. Nutting CM, Robinson M, Birchall M. Survival from laryngeal cancer in England and Wales up to 2001. Br J Cancer. 2008;99 Suppl 1:S38-9.

31. Rachet B, Quinn MJ, Cooper N, Coleman MP. Survival from cancer of the larynx in England and Wales up to 2001. Br J Cancer. 2008;99 Suppl 1:S35-7. 